\title{
Polymorphism of the pig $L M X 1 A$ gene, localized within the FAT1 region, is not associated with growth and fatness
}

\author{
A. Chmurzynska ${ }^{2}$, M. Grzes ${ }^{1}$, D. Kregielska ${ }^{1}$ and M Switonski ${ }^{1,3}$ \\ Poznan University of Life Sciences, \\ ${ }^{1}$ Department of Genetics and Animal Breeding, \\ ${ }^{2}$ Department of Human Nutrition and Hygiene \\ Wotyńska 33, 60-637 Poznań, Poland
}

(Received 31 August 2010; revised version 22 November 2010; accepted 26 November 2010)

\begin{abstract}
The LMX1A gene, located within the $3.3 \mathrm{cM}$ FAT1 QTL on porcine chromosome 4, was tested as a positional and functional candidate for fatness traits. A gene fragment consisting of the partial promoter, 5'UTR, exon 1, and partial intron 1, was sequenced in a panel of 79 pigs of Polish Large White (PLW), Polish Landrace (PL), Duroc and Pietrain breeds. Only a G to A substitution in intron 1 (182 bp upstream of the translation start site) was found. In total, 738 gilts were genotyped: 191 PLWs, 249 PLs, 239 of synthetic line 990 (L990), 21 Pietrain and 38 Duroc. The genotype distributions appeared to be breed-specific. Association studies were performed for 12 growth and fatness traits in the PLW, PL and L990 pigs and no association was found. The only result which approached the significance level $(\mathrm{P}=0.047)$ concerned the lean meat content. Our results indicate that the $L M X 1 A$ gene should not be considered as a candidate gene for QTL in the FAT1 region in the studied Polish pig breeds.
\end{abstract}

KEY WORDS: pig, fatness, FAT1, QTL, $L M X 1 A$, SNP

\section{INTRODUCTION}

Genetic dissection of complex traits has attracted much attention in recent years. Human obesity, as well as fatness traits in the pig, are polygenic traits with

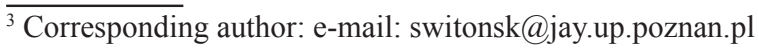


a heritability coefficient of around 0.5 (for a review see Switonski et al., 2010). Many quantitative trait loci (QTL) affecting fat deposition and weight gain have been identified in porcine chromosome 4 (http://www.animalgenome.org/cgi-bin/ QTLdb/SS/index).

A QTL with a major effect on fatness was initially identified on porcine chromosome 4 by Andersson et al. (1994), and was later named FAT1 by Marklund et al. (1999). Mercade et al. (2006) postulated that the FABP4 gene is a positional candidate gene for the FAT1 locus. Similar results were presented by Estelle et al. (2006), who proposed that the position of FAT1 lay between the FABP4 and $F A B P 5$ genes. However, FISH localization of the FABP gene cluster revealed that it is located outside the FAT1 region (Szczerbal et al., 2007).

Further refinements in the localization of FAT1 narrowed this region to $3.3 \mathrm{cM}$, with the assumption that a single gene is responsible for the observed effect (Berg et al., 2006). One of the genes located within this shortened region encodes LIM homeobox transcription factor 1 alpha $(L M X 1 A)$. The LMX1A transcription factor was shown to activate insulin gene transcription (German et al., 1992) and it has been considered as a functional candidate for type 2 diabetes. The human $L M X 1 A$ gene consists of 11 exons, including three alternatively spliced exons (4A, 4B and 6A) (Thameem et al., 2002). Organization of the porcine gene is not yet described, but linkage mapping has assigned the gene to SSC4 (ATP1B1 - 1.9cM - LMXIA 1.8 - S0073), within QTL intervals for meat weight (Horak et al., 2010).

The aim of the present study was to search for polymorphic variants of the $L M X 1 A$ gene, and to analyse the distribution of the polymorphism in four pig breeds and in one synthetic line. Moreover, association of the identified SNP with the porcine production traits - including daily gain, feed conversion ratio, and ten fatness traits - was evaluated.

\section{MATERIAL AND METHODS}

The analysed pig groups included gilts (halfsibs and fullsibs) of the Polish Large White (PLW, $n=191)$, Polish Landrace (PL, $n=249)$, Duroc $(n=38)$ and Pietrain ( $\mathrm{n}=21$ ) breeds, and the synthetic line 990 (L990, $\mathrm{n}=239$ ).

Based on the porcine sequence downloaded from the EMBL database (accession number CU462963.10) a PCR primer set was designed: LMX1A-F 5' TTG GGG CGG AGT CGT TCT TGG AGT, and LMX1A-R 5' TGG GGC GGC TTG TCA GTT TAG G. The amplified 603 bp region consisted of the partial promoter, 5'UTR, exon 1 and partial intron 1 of the LMXIA gene (according to the human $L M X 1 A$ gene organization). Amplification was performed on genomic DNA $(100 \mathrm{ng})$. Reaction mixtures also contained $2 \mu \mathrm{l}$ of $10 \times \mathrm{PCR}$ buffer $(700 \mathrm{mM}$ 
Tris- $\left.\mathrm{HCl} \mathrm{pH} 8.6 ; 166 \mathrm{mM}\left(\mathrm{NH}_{4}\right)_{2} \mathrm{SO}_{4}, 25 \mathrm{mM} \mathrm{MgCl}{ }_{2}\right), 10$ pmol of each primer, $125 \mu \mathrm{M}$ of dNTPs and $1 \mathrm{U}$ Taq polymerase, and $1 \mu \mathrm{L}$ DMSO. The cycling profile was $94^{\circ} \mathrm{C}$ for $5 \mathrm{~min}$ followed by 30 cycles of $94^{\circ} \mathrm{C}$ for $1 \mathrm{~min} ; 56.6^{\circ} \mathrm{C}$ for $1 \mathrm{~min}$, $72^{\circ} \mathrm{C}$ for $1 \mathrm{~min}$ and finally $72^{\circ} \mathrm{C}$ for $10 \mathrm{~min}$.

Altogether 79 samples (10 PLW, 10 PL, 21 Pietrain, and 38 Duroc) were sequenced in a Genetic Analyzer 3130 (Applied Biosystems). Before sequencing, the PCR products were cleaned with Exonuclease I and Shrimp Alkaline Phosphatase by incubation for $30 \mathrm{~min}$ at $37^{\circ} \mathrm{C}$ and $15 \mathrm{~min}$ at $80^{\circ} \mathrm{C}$, respectively. Then sequencing reaction with the use of four BigDye terminators was conducted under the following conditions: $95^{\circ} \mathrm{C}$ for $20 \mathrm{~s}, 25$ cycles of $95^{\circ} \mathrm{C}$ for $12 \mathrm{~s}, 51^{\circ} \mathrm{C}$ for $8 \mathrm{~s}, 60^{\circ} \mathrm{C}$ for $240 \mathrm{~s}$. The obtained PCR products were purified with the ExTerminator system (A\&A Biotechnology, Gdansk, Poland) according to the manufacturer's protocol, and sequenced in both directions.

The genotyping for the identified SNP was performed by digestion of PCR products with $D d e$ I restriction enzyme for $16 \mathrm{~h}\left(37^{\circ} \mathrm{C}\right)$ and separation of DNA fragments on $2 \%$ agarose gel.

The association between $L M X 1 A$ polymorphism and 12 production traits (average daily gain, feed conversion ratio (FCR), backfat thickness measured at 7 points (BFT), abdominal fat weight and intramuscular fat content (IMF)) was tested within each breed with the SAS mixed procedure (SAS Inst. Inc. Cary, NC, 2008). The model for each trait included the fixed effects of the genotypes at the RYR I and LMXIA loci, linear covariates of age at slaughter and carcass weight (excluded for growth and FCR), average backfat thickness (for IMF), and the random effect of the sire. Due to very low frequency of the AA genotype, it was excluded from the association analysis in PL and L990. For PLW we fitted the general, additive, dominance, and recessive models.

\section{RESULTS}

The $603 \mathrm{bp}$ fragment of the $L M X 1 A$ gene including the promoter, exon 1, and partial intron 1 was amplified and sequenced for pigs of PLW, PL, Duroc and Pietrain breeds. The sequencing resulted in the identification of only one single nucleotide polymorphism (SNP) in intron 1 - a G to A substitution at position $106 \mathrm{bp}$ in intron 1, $182 \mathrm{bp}$ upstream of the translation start site. The RFLP test, based on digestion with $D d e$ I restriction enzyme, was performed. The G allele was the major allele in the PLW, PL, L990 and Pietrain pigs. However, the genotype distribution was breed-specific (Table 1). Pairwise comparison of the genotype distributions showed no significant difference only in the cases of the PL and L990 and Pietrain and Duroc pairs (Table 2). No evidence for deviation from HardyWeinberg equilibrium in any of the tested groups was found (Pearson test). 
Table 1. Distribution of G/A polymorphism of the $L M X 1 A$ gene

\begin{tabular}{lcccc}
\hline \multirow{2}{*}{ Breed or synthetic line } & \multirow{2}{*}{$\mathrm{n}$} & \multicolumn{3}{c}{ Genotypes } \\
\cline { 3 - 5 } & & $\mathrm{GG}$ & $\mathrm{AG}$ & $\mathrm{AA}$ \\
\hline PLW & 191 & 0.51 & 0.40 & 0.09 \\
PL & 249 & 0.77 & 0.22 & 0.01 \\
L990 & 239 & 0.84 & 0.15 & 0.01 \\
Pietrain & 21 & 0.19 & 0.67 & 0.14 \\
Duroc & 38 & 0.13 & 0.45 & 0.42 \\
\hline
\end{tabular}

${ }^{1}$ PLW - Polish Large White; PL - Polish Landrace; L990 - synthetic line 990

Table 2. Pairwise comparison of the genotype distribution in the analysed pig breeds.

\begin{tabular}{lccccc}
\hline Breed $^{1}$ & PLW & PL & L990 & Pietrain & Duroc \\
\hline PLW & $\mathrm{X}$ & & & & \\
PL & $\mathrm{P}<0.001$ & $\mathrm{X}$ & & & \\
L990 & $\mathrm{P}<0.001$ & $\mathrm{NS}$ & $\mathrm{X}$ & & \\
Pietrain & $\mathrm{P}<0.05$ & $\mathrm{P}<0.001$ & $\mathrm{P}<0.001$ & $\mathrm{X}$ & \\
Duroc & $\mathrm{P}<0.001$ & $\mathrm{P}<0.001$ & $\mathrm{P}<0.001$ & $\mathrm{NS}$ & $\mathrm{X}$ \\
\hline
\end{tabular}

NS - not significant; ${ }^{1}$ explanation - see Table 1

Statistical analysis did not reveal significant association between the $\mathrm{A} / \mathrm{G}$ polymorphism and the analysed production traits $(0.047<\mathrm{P}<0.992)$. The only trait which approached the significance level in the PLW breed was the lean meat content under the additive model $(\mathrm{P}=0.047)$. The additive effect of the $\mathrm{G}$ allele was estimated as $+0.571( \pm 0.286)$.

\section{DISCUSSION}

This study on the genetic background of pig fatness traits showed that in spite of the quite high heritability of these traits, identification of a causative or an associated polymorphism is rather unsuccessful (Switonski et al., 2010). Genome scanning analyses facilitated identification of numerous QTL regions for porcine production traits. Interestingly, 501 out of 5621 QTLs in the pig genome have been assigned to porcine chromosome 4 (http://www.animalgenome.org/QTLdb). The great majority of them concern meat quality traits (3985 QTLs in the whole genome), including QTLs for average daily gain and fat deposition (abdominal fat weight, backfat thickness and intramuscular fat).

The QTL for growth and fatness in chromosome 4, called FAT1, was the first to be identified in the pig genome (Andersson et al., 1994). Until now no functional polymorphism of this region responsible for the phenotypic variability had been identified. Several positional and functional candidate genes located on porcine 
chromosome 4 and/or within the FAT1 region were tested. Studies concerning the adipocyte fatty acid binding-protein gene (FABP4) gave rather ambiguous results (Gerbens et al., 1998, 2000; Chmurzynska et al., 2004, 2008). Most recently the association between SNP in the porcine cathepsin K (CTSK) gene and fatness traits was analysed. The chromosomal location of the CTSK gene is close to the FAT1 region. Intronic SNP of the CTSK locus was associated with backfat thickness in Italian Duroc pigs (Fontanesi et al., 2010). In the present study, LMX1A was tested as a positional and functional candidate gene. A single $\mathrm{SNP}(\mathrm{G}>\mathrm{A}$ in intron 1) was detected and the genotype distribution was breed-specific. The occurrence of this SNP was reported very recently also by Horak et al. (2010) who described it as g. $155 \mathrm{G}>$ A. These authors also detected 4 other SNPs, but the genotype distribution in 8 breeds was analysed only for g.1203C $>\mathrm{T}$ polymorphism. As in our studies, the observed allele frequencies were uneven across the breeds.

The $\mathrm{G}$ to A substitution in intron 1 was not associated with fatness traits in the PLW ( $\mathrm{n}=187$ animals) or PL $(\mathrm{n}=243)$ breeds, or in the L990 $(\mathrm{n}=239)$ synthetic line. Since only a small fragment of this gene was screened, it cannot be excluded that other polymorphic variants of this gene may show association with fatness traits. However, we assume that if such polymorphism would be present in these breeds a linkage disequilibrium should reflect the association with the studied SNP. Interestingly, in humans the $L M X 1 A$ gene was considered to be a potential positional and functional candidate gene for type 2 diabetes (T2D). However, the reported results are not concordant. Thameem et al. (2002) concluded that polymorphism of this gene did not contribute significantly to T2D etiology in Pima Indians (Thameem et al., 2002). On the other hand, an evidence of association between two intronic SNPs of the LMX1A and T2D in the British population has been reported by Wongseree et al. (2009).

\section{CONCLUSIONS}

To our knowledge this is the first report of association studies between the polymorphism of the $L M X 1 A$ gene and the variability of porcine productive traits. The studied G $>$ A SNP (intron 1) showed uneven distribution in the studied breeds, but was not associated with the analysed traits. This allows us to conclude that the $L M X 1 A$ gene cannot be considered in Polish breeds as a candidate gene of the FAT1 region. 


\section{REFERENCES}

Andersson L., Haley C.S., Ellegren H., Knott S.A., Johansson M., Andersson K., Andersson-Eklund L., Edfors-Lilja I., Fredholm M., Hansson I., Hakansson J., Lundstrom K., 1994. Genetic mapping of quantitative trait loci for growth and fatness in pigs. Science 263, 1771-1774

Berg F., Stern S., Andersson K., Andersson L., Moller M., 2006. Refined localization of the FAT1 quantitative trait locus on pig chromosome 4 by marker-assisted backcrossing. BMC Genet. 7-17

Chmurzynska A., Cieslak J., Jankowski T., Szydlowski M., Switonski M., 2008. Identification of target sequences for association studies - analysis of the pig FABP3 and FABP4 loci using comparative genomics methods. J. Anim. Feed Sci. 17, 191-201

Chmurzyńska A., Maćkowski M., Szydłowski M., Melonek J., Kamyczek M., Eckert R., Różycki M., Świtonski M., 2004. Polymorphism of intronic microsatellites in the A-FABP and LEPR genes and their association with productive traits in the pig. J. Anim. Feed Sci. 13, 615-624

Estellé J., Pérez-Enciso M., Mercadé A., Varona L., Alves E., Sánchez A., Folch J.M., 2006. Characterization of the porcine FABP5 gene and its association with the FAT1 QTL in an Iberian by Landrace cross. Anim. Genet. 37, 89-91

Fontanesi L., Scotti E., Buttazzoni L., Dall'Olio S., Davoli R., Russo V., 2010. A single nucleotide polymorphism in the porcine cathepsin K (CTSK) gene is associated with back fat thickness and production traits in Italian Duroc pigs. Mol. Biol. Rep. 7, 491-495

Gerbens F., deKoning D.J., Harders F.L., Meuwissen T.H.E., Janss L.L.G., Groenen M.A.M., Veerkamp J.H., vanArendonk J.A.M., te Pas M.F.W., 2000. The effect of adipocyte and heart fatty acid-binding protein genes on intramuscular fat and backfat content in Meishan crossbred pigs. J. Anim. Sci. 78, 552-559

Gerbens F., Jansen A., Van Erp A.J.M., Herders F., Meuwissen T.H.E., Rettenberger G., Veerkamp J.H., te Pas M.F.W., 1998. The adipocyte fatty acid-binding protein locus: characterization and association with intramuscular fat content in pigs. Mamm. Genome 9, 1022-1026

German M.S., Wang J., Chadwick R.B., Rutter W.J., 1992. Synergistic activation of the insulin gene by a LIM-homeodomain protein and a basic helix-loop-helix protein: building a functional insulin minienhancer complex. Gene. Develop. 6, 2165-2176

Horák P., Stratil A., Svatonová M., Mastalková L., Patáková J., Van Poucke M., Bartenschlager H., Peelman L.J., Geldermann H., 2010. Polymorphism screening and mapping of nine meat performance-related genes in the pig. Anim. Genet. 41, 334-345

Marklund L., Nystrom P., Stern S., Andersson-Eklund L., Andersson L., 1999. Confirmed quantitative trait loci for fatness and growth on pig chromosome 4. Heredity 82, 134-141

Mercadé A., Pérez-Enciso M., Varona L., Alves E., Noguera J.L., Sánchez A., Folch J.M., 2006. Adipocyte fatty-acid binding protein is closely associated to the porcine FAT1 locus on chromosome 4. J. Anim. Sci. 84, 2907-2913

Switonski M., Stachowiak M., Cieslak J., Bartz M., Grzes M., 2010. Genetics of fat tissue accumulation in pigs: a comparative approach. J. Appl. Genet. 51, 153-168

Szczerbal I., Chmurzynska A., Switonski M., 2007. Cytogenetic mapping of eight genes encoding fatty acid binding proteins (FABPs) in the pig genome. Cytogenet. Genome Res. 118, 63-66

Thameem F., Wolford J.K., Wang J., German M.S., Bogardus C., Prochazka M., 2002. Cloning, expression and genomic structure of human LMX1A, and variant screening in Pima Indians. Gene 290, 217-225

Wongseree W., Assawamakin A., Piroonratana T., Sinsomros S., Limwongse C., Chaiyaratana N., 2009. Detecting purely epistatic multi-locus interactions by an omnibus permutation test on ensembles of two-locus analyses. BMC Bioinform. 10, 294 